\title{
MIRACLE DIETS
}

\section{When eating guidelines cause health problems}

JOSÉ MigUEL SORIANO DEL CASTILLO AND Ma INMACULADA ZARZO LLOBELL

Globally, 1.9 billion adults are overweight, 650 million of which are obese, which in turn impacts both health and the economy. Treating obesity involves strategies such as physical activity and dietary planning, always under the supervision of healthcare professionals. Recent decades have brought many fad diets, although they originated at the beginning of the twentieth century. However, these can lead to health problems among their users. A practical way to detect them is that they promise rapid weight loss (more than $1 \mathrm{~kg}$ per week), are allegedly effortless, impose excessive energy restrictions, and exclude food or nutrients from the diet.

Keywords: fad diets, mono diets, Atkins diet, health, obesity.

At the end of the twentieth century, obesity, a multifactorial chronic disease characterised by an excessive accumulation of fat, was already considered a pandemic: more than 300 million adults and around 25 million children and adolescents were overweight (WHO, 2000). This situation was not solved even with global, national, and local food policies, and is now even more alarming (WHO, 2016) with over 1.9 billion adults currently overweight, 650 million of which are obese, and more than 340 million overweight or obese children and adolescents.

In Spain, this exponential change is evident in the fact that one in ten children and adolescents are obese, according to the information provided in the National Health Survey (Ministerio de Sanidad, Consumo y Bienestar Social, 2018). In addition to the effect this has on the healthcare system, it also has a powerful economic impact because almost 2 billion euros from the Spanish National Health System (2016) are devoted to mitigate the direct cost of treating excess weight, to which we must add a similar amount in costs related to work incapacity and the loss of productivity (Hernáez et al., 2019). This is certainly interesting, because this is the same amount Spanish citizens spend on miracle products or weight loss books, even though $67 \%$ of the nutritional information they include has no scientific basis (FESNAD, 2008).
In the field of health, and according to the International Agency for Research on Cancer (IARC, 2018), obesity can increase the predisposition to suffer several types of cancer (colon and rectum, oesophagus, kidney - renal cell carcinoma -, liver, gallbladder, pancreas, ovary, thyroid, uterine lining, prostate, breast in postmenopausal women and men -, stomach tumours, and meningioma and multiple myeloma). It can also increase the prevalence of pathologies related to the cardiovascular system (heart failure and arrhythmias, among others), gastrointestinal system (such as gastroesophageal reflux disease and fatty liver), endocrine system (diabetes), renal and genitourinary system (like erectile dysfunction and chronic kidney failure), obstetric system (foetal distress), dermal system (stretch marks, acanthosis nigricans, and cellulitis), muscle and skeletal system (predisposition to gout, osteoarthritis, and back pain), neurological system (stroke and meralgia paresthetica), and respiratory system (dyspnoea, obstructive sleep apnoea, and asthma), as well as psychological disorders (depression and low self-esteem).

The tools available to fight obesity are physical activity and energy intake restriction, as well as cognitive-behavioural treatment, pharmacological treatment, and bariatric surgery (National Institute for 
Health and Care Excellence, 2014) - although the two latter options should only be used when the rest have failed. The objective of dietary plans to restrict energy intake and guidelines to increase physical activity is to achieve a negative energy balance. Thus, the body must obtain energy from the reserves of fat stored in its adipose tissue, constituting the largest energy reserve of the body. However, a great variety of diets are now available that, based on different principles, seek a rapid decrease in weight without a proper evaluation of their effectiveness and impact on health.

There is no place today for the so-called drawer diets, which were given to patients without considering their tastes, total energy consumption, lifestyle, or food dislikes. Only the intervention of a personalised nutrition plan established by a dietitian-nutritionist will allow patients to achieve a healthy goal and keep them from falling into so-called fad diets (also known as magical or miracle diets).

\section{THE DIET, THE GREAT UNKNOWN}

If we search for diets on Google, we get over 85 million results, and although the relationship between obesity and diet is already clear in the minds of the population, the concept of a diet as a whole does not seem to be so clear. The term comes from the Latin word diaeta, which in turn comes from Greek diaita, meaning "way of life". The dictionary of the Royal Spanish Academy (RAE, in its Spanish acronym) offers three definitions. First, as an «eating and drinking regime that patients or convalescent people must follow and, by extension, the foods and drinks in that regime»; second, as a «set of substances that are regularly ingested as food»; and, lastly, as the «complete deprivation of eating». On the other hand, the UN Food and Agriculture Organization (FAO, n.d., p. 128) defines diet as the «Mix of solid and liquid foods consumed by an individual or group. Its composition depends on the availability and cost of food, as well as the eating habits and cultural value of certain foods».

All these definitions present several problems. In the case of the first definition in the RAE, including only patients or convalescent individuals is a mistake. A diet can, for instance, be considered for several physiological situations such as a pregnancy or childhood, not just for pathological situations. The second definition is the closest to reality, although the intended goal to prescribe those substances should be

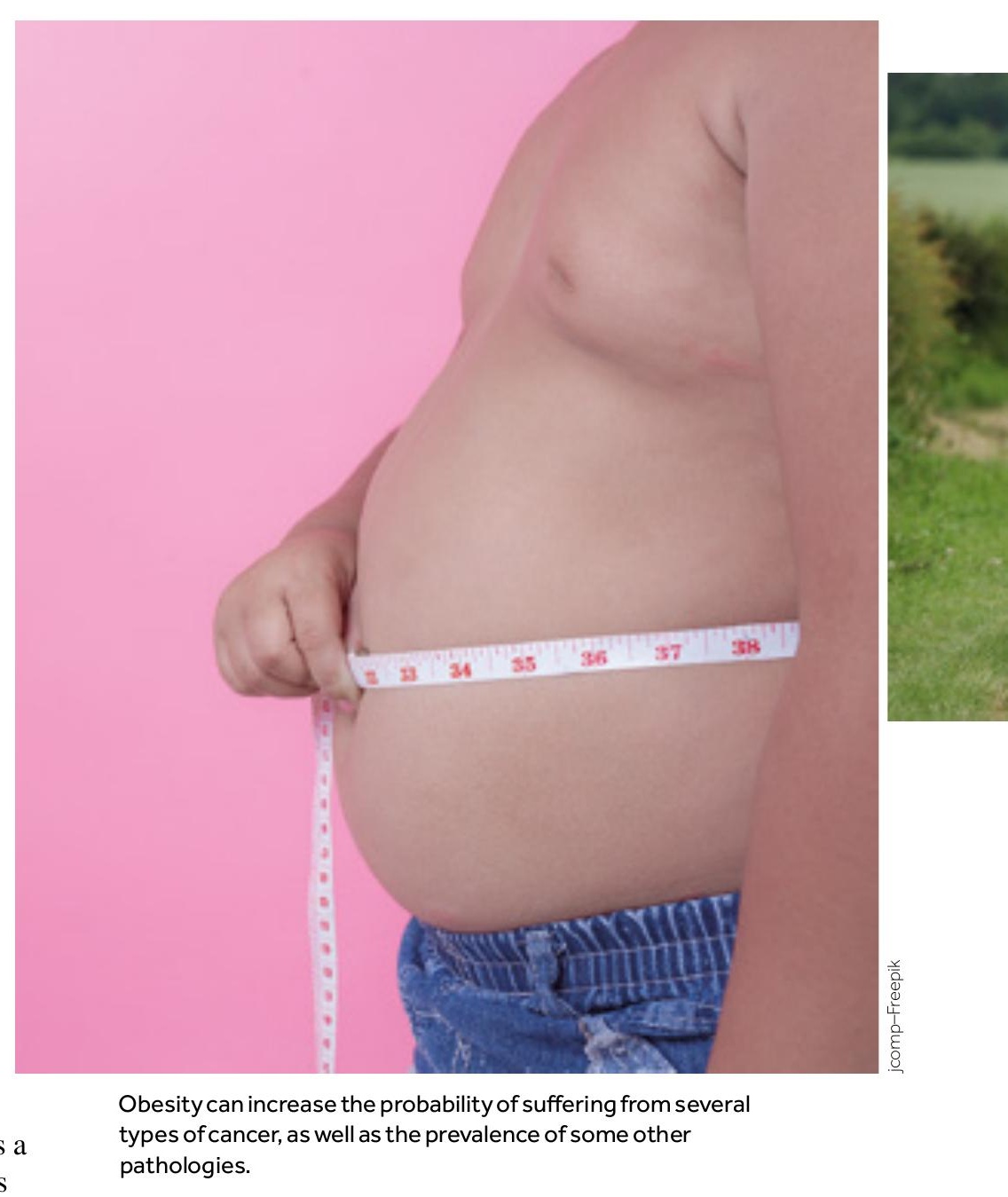

specified. The third entry focuses more on fasting. On a practical level, it would now be more appropriate to use a definition closer to the following: «liquid or solid foods established by a dietitian-nutritionist for users or patients in a particular physiological or pathological situation to help them establish the best possible lifestyle regime».

The first diet in history was found in the Ebers Papyrus, dates back around 1,550 BCE, and was acquired in 1872 by the Egyptologist George Ebers in Luxor. It includes around 250 clinical profiles. A diet is described for one of them, based on a mixture of wheat semolina, dates, and Nubian ochre, presented in an aqueous preparation, which should be taken for four days for patients with symptoms similar to those of diabetes (Ebers, 1873).

However, the first weight-loss diet did not appear until the early twentieth century, thanks to an entrepreneur, Horace Fletcher. He praised the effectiveness of a treatment that allowed him to chew each bite up to one hundred times in the loss of $18 \mathrm{~kg}$, which earned him the nickname «the great 


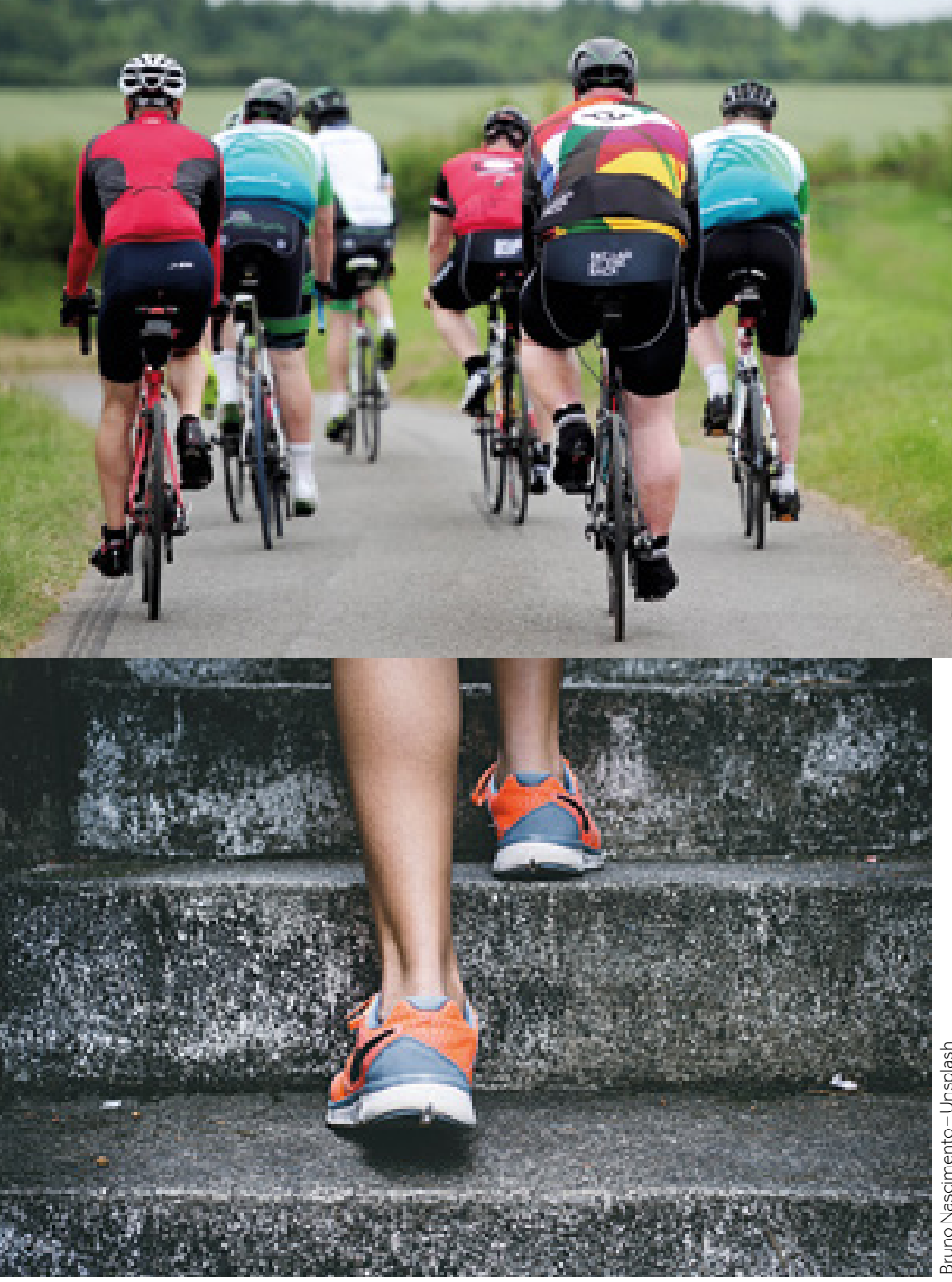

The objective of a dietary plan that restricts energy intake and offers guidelines to increase physical activity is to reach a negative energy balance.

\section{«There is no place today for the so-called drawer diets, which were given to patients without considering their tastes, total energy consumption, lifestyle, or food dislikes»}

masticator». He decided to publish a book that became a best seller (Fletcher, 1903) and coined two new terms: fletcherism (a diet following Horace Fletcher's principles) and fletcherising (the action of chewing according to fletcherism). One of the greatest advocates for this new technique, which he put into practice at the Battle Creek Sanatorium, was Dr. John Harvey Kellogg, the inventor of the breakfast cereals. But Fletcher was touting something a little more extreme: he believed we should chew each bite without swallowing it until the food is liquid (which is somewhat complicated for many foods).

It is true that today, due to the stress in our lives, among other reasons, we do not masticate food properly. Rather than chewing, we just swallow. If we chew properly, slowly, and for an adequate time, one of the effects we would observe is that we would become satiated earlier, so we would consume less food, leading to a lower energy intake and, therefore, to weight loss. This data was reflected in a 2011 study by researchers at Oxford Brookes University, which compared two groups of participants. One of the groups masticated each bite 35 times, while the other chewed it ten times; food intake was reduced in the first group (Smit et al., 2011).

\section{FAKE, MAGICAL, MIRACLE, AND UNHEALTHY DIETS}

From Fletcher's writing to the present day, it is estimated that more than a thousand diets have appeared, most of them dangerous due to their associated risks to our health. In Spain, the first ineffective diets were collected in the 1994 Vitoria meeting, where Professor Arnold Bender indicated that millions of people follow the most absurd diets and that these diets were scamming people. It was the first recorded use of the concept of a «magical diet» (Bender, 1994). The term was recovered three years later by Varela, Núñez, Moreiras, and Grande Covián (1998) in their technical public health document for the region of Madrid (Documento técnico de salud pública de la Comunidad de Madrid). They referred to diets claiming to result in weight loss, increased lifespan, and the curation of several pathologies based on unverified virtues attributed to «natural» foods or products. The document was expanded upon eleven years later by the Spanish Nutrition Foundation and 
Nutrition and Eating Disorders Institute of the Region of Madrid (FEN \& INUTCAM, 2009).

In 2008, following the Nutrition Day, the Spanish Federation of Nutrition, Food and Dietetics (FESNAD) launched the campaign «Tu dieta es tu vida. ¡Cuídala! Las dietas milagro no existen» ("Your diet is your life. Take care of it! Miracle diets don't exist"), which thoroughly described and classified these diets (Table 1). In the following, we will describe an instance of each of these diet types.

Dr. Shelton's diet was created by Herbert McGolfin Shelton, who had studied at the American School of Chiropractice and graduated as a doctor in naturopathy from the American School of Naturopathy. His diet was based on the concept of dissociation and although it focused on vegetarians at first, it was later modified to incorporate more nonvegetarian patients. He promised weight loss of up to $1.5 \mathrm{~kg}$ per week. After 1927, and during the following three decades, he was arrested, imprisoned, and fined for practicing medicine without a license. He was also charged with negligent homicide after one patient starved to death and another one died of a heart attack, and this sentence led him to bankruptcy (Varela et al., 1998).

The Gayelord diet was developed in the 1920s by Benjamin Gayelord Hauser, a graduate in naturopathy and chiropractice (Carstairs, 2014). It was based on a seven-day elimination diet with a fasting day which only allowed the consumption of juice. Together with his brother-in-law, he started marketing products for use in patients. At the same time, the diet spread in Hollywood because some great stars of the time, such as Fred Astaire, Ingrid Bergman, Marlene Dietrich, Greta Garbo, Paulette Goddard, Grace Kelly, Jeanne Moreau, Gloria Swanson, and the Duchess of Windsor, used it. He called himself a «nutrition advisor» because he had not completed any medical studies and was not a doctor. He promised weight loss of up to $1.5 \mathrm{~kg}$ per week, but following this diet can lead to insufficient intake of vitamins and minerals (Drouard, 1998).

The Atkins diet was proposed in the 1960s by the US cardiologist Robert Coleman Atkins. After reading a scientific article supporting the idea that the restriction of carbohydrate-rich foods led to weight loss, he decided to try it and observed that the effect was indeed real. Later, he published a book titled Dr. Atkins' Diet Revolution (Atkins, 1972), in which he advised against the consumption of milk, fruit, almost all vegetables, bread, pasta, cereals, sugar, and pastries. Conversely, he imposed no limits on the consumption of meat, fish, eggs, cured meats, some cheeses, fats, and oils, offal, and seafood. He promised weight loss of up to $2 \mathrm{~kg}$ per week. Christman (2002) indicated that more interventions or studies were necessary to be able to discuss the benefits and adverse effects of the Atkins diet, because the available results were short term and used very small sample sizes. The book was reissued in 1992 under the title $D r$. Atkins' New Diet Revolution. Its precepts had relaxed to allow the consumption of more vegetables to increase the fibre intake, and slightly increased carbohydrate consumption.

At the end of the twentieth century, a number of experiments showed that patients on the Atkins diet consume fewer calories. It is believed that, because so few carbohydrates are available to them, fats actually control their appetite, causing a satiating effect (Christman, 2002; Rolls et al., 1994). This last study indicated that, even though fat's satiating

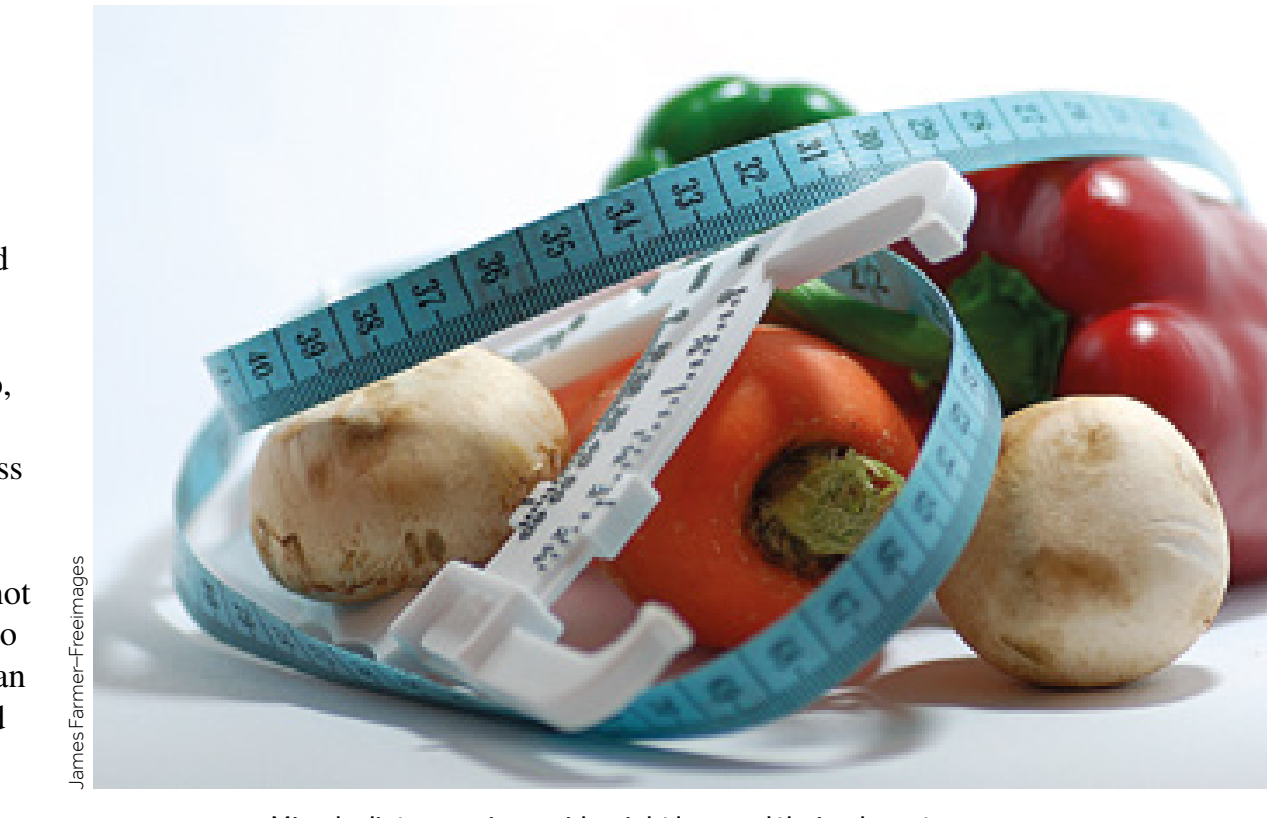

Miracle diets promise rapid weight loss and their advocates claim that they can be followed effortlessly. These diets impose excessive energy restrictions and exclude foods or nutrients that are important for our bodies. 
Table 1. Fad diet classifications.

\begin{tabular}{|c|c|c|c|}
\hline Diet type & Characteristics & Examples & Problems \\
\hline $\begin{array}{l}\text { Diets with a low } \\
\text { or very low caloric } \\
\text { value }\end{array}$ & $\begin{array}{l}800-1,000 \text { and } 400-800 \\
\text { kcal/day, respectively }\end{array}$ & $\begin{array}{l}\text { - Dissociated } \\
\text { - Triple-factor } \\
\text { - Open } \\
\text { - Shelton }\end{array}$ & $\begin{array}{l}\text { - Gastrointestinal, gynaecological, } \\
\text { and dermal problems, sleep } \\
\text { disorders, depression }\end{array}$ \\
\hline $\begin{array}{l}\text { Hypoenergetic } \\
\text { diets }\end{array}$ & $1,000-1,200 \mathrm{kcal} / \mathrm{day}$ & $\begin{array}{l}\text { - Gayelord } \\
\text { - Carrot-only diet } \\
\text { - Asparagus diet } \\
\text { - Artichoke diet }\end{array}$ & $\begin{array}{l}\text { - Inadequate vitamin and mineral } \\
\text { intake }\end{array}$ \\
\hline $\begin{array}{l}\text { Low carbohydrates, } \\
\text { with high protein } \\
\text { and fat }\end{array}$ & $\begin{array}{l}\text { Low intake of } \\
\text { carbohydrates and high } \\
\text { intake of foods with } \\
\text { significant protein and fat } \\
\text { content }\end{array}$ & $\begin{array}{l}\text { - Dr. Atkins diet } \\
\text { - Scardale diet } \\
\text { - Mayo Clinic diet } \\
\text { - Montignac diet }\end{array}$ & $\begin{array}{l}\text { - Increased cholesterol, } \\
\text { triglycerides, and uric acid } \\
\text { - Loss of muscle and visceral } \\
\text { protein } \\
\text { - Gastrointestinal disorders } \\
\text { - Bad breath, nausea, dizziness, } \\
\text { lack of appetite, fatigue, and } \\
\text { decalcification } \\
\text { - Without dietary planning, it can } \\
\text { lead to kidney and brain damage }\end{array}$ \\
\hline $\begin{array}{l}\text { Rich in } \\
\text { carbohydrates }\end{array}$ & $\begin{array}{l}\text { Low protein }(0.5 \mathrm{~g} / \mathrm{kg} / \text { day }) \\
\text { and fat ( } 10 \% \text { or less of the } \\
\text { total energy intake) }\end{array}$ & $\begin{array}{l}\text { - Lemonade cleanse } \\
\text { and maple syrup diet } \\
\text { - Pineapple diet } \\
\text { - Brown rice diet }\end{array}$ & $\begin{array}{l}\text { - Potential lack of some nutrients } \\
\text { such as essential fatty acids, fat- } \\
\text { soluble vitamins, and proteins } \\
\text { - Gastrointestinal problems } \\
\text { (lower absorption of minerals, } \\
\text { abdominal cramps, diarrhoea, } \\
\text { and gas) }\end{array}$ \\
\hline Mono diet & $\begin{array}{l}\text { Based on consuming one } \\
\text { particular food }\end{array}$ & $\begin{array}{l}\text { - Grapefruit diet } \\
\text { - Soup diet } \\
\text { - Grape diet } \\
\text { - Ice cream diet }\end{array}$ & $\begin{array}{l}\text { - Monotonous, boring, and } \\
\text { unbalanced, both energetically } \\
\text { and nutritionally } \\
\text { - They can potentially cause } \\
\text { digestive and psychological } \\
\text { disorders }\end{array}$ \\
\hline Eccentric & $\begin{array}{l}\text { Diets that use some } \\
\text { kind of quirk to convince } \\
\text { people that they are easy } \\
\text { to follow }\end{array}$ & $\begin{array}{l}\text { - Garlic diet } \\
\text { - Calendar diet } \\
\text { - Mental diet } \\
\text { - Colour diet } \\
\text { - Beverly Hills diet }\end{array}$ & - Nutritional imbalances \\
\hline
\end{tabular}


effect was significantly lower than that of carbohydrates for some individuals, it would lead to an increase in energy consumption. Atkins died without understanding the actual biological mechanism of his own diet. On a different note, doctor Arne Vernon Astrup, a researcher in the Department of Human Nutrition of RVA University in Copenhagen, carried out a review analysing 107 papers and noted that there was no evidence that the Atkins diet was useful for long-term weight loss, although it might be safe for short periods up to six months (Astrup et al., 2004). The Atkins diet achieves weight loss during the first few days, due to the use of glycogen and body water. However, it has been shown that it can increase the amount of plasma cholesterol and uric acid (leading to gout), and patients who have stopped this diet have rapidly gained weight when their glycogen and body water stores were replenished (Christman, 2002).

The lemonade diet and the maple syrup diet were developed by naturopath Stanley Burroughs who published a book describing this diet in 1976. It consisted of fasting for ten days or more while consuming only a drink made with lemon juice, maple syrup, and cayenne pepper, together with a laxative tea and water with sea salt. After these days, some foods such as vegetables, vegetable soup, and fruits could be gradually incorporated. $\mathrm{He}$ promised weight loss of up to 5 kg per week (Burroughs, 1976). This diet causes protein, vitamin, and mineral deficiencies, as well as halitosis (bad breath), fatigue, insomnia, dizziness, and drops in blood pressure, among other effects. In 1984, Burroughs was convicted of unlawfully selling treatments against cancer, practicing without a license, and for the second-degree murder of Lee Swatsenbarg - a cancer patient who followed his treatment - by the Supreme Court of California (Trimble, 1985).

The grapefruit diet, also known as the Hollywood diet, became popular in the early 1930s, claiming that fruit contains flavonoids that stimulate the body to burn fat and speed up metabolism. It was proposed as an eighteen-day diet associated with a low-calorie intake (between 800 and 1,000 kcal). The

\section{«Only the intervention of a personalised nutrition plan established by a dietitian- nutritionist will allow patients to achieve a healthy goal and keep them from falling into so-called fad diets»}

At the beginning of the twentieth century, the first weight loss et was presented by the entrepreneur Horace Fletcher, who claimed to have lost $18 \mathrm{~kg}$ by chewing every bite of food up to one

fact is that this association (low energy intake and fibre consumption from fruit) would be the reason for the weight loss. It is discouraged for patients medicated with immunosuppressants, some statins, benzodiazepines, most calcium channel blockers, indinavir, and carbamazepine, because grapefruit juice inhibits CYP3A4, the isoenzyme of cytochrome $\mathrm{P} 450$, which is involved in the metabolisation of these medicines (Modi \& Priefer, 2020).

Lastly, we would like to mention the garlic diet, which, in the words of Varela et al. (1998), «consists of placing a peeled garlic clove on the bellybutton, which will feel uncomfortable when the individual snacks» (pp. 29-30).

These and other similar diets are still present in our everyday lives. However, resources are available to detect them: all of them promise rapid weight loss (more than $1 \mathrm{~kg}$ per week), their advocates claim they can be followed effortlessly, they impose excessive energy restrictions, and the diet excludes foods or nutrients that are important for our bodies. These diets can endanger the health of individuals because they do not incorporate balanced and sufficient amounts of the nutrients necessary for normal body functioning. 


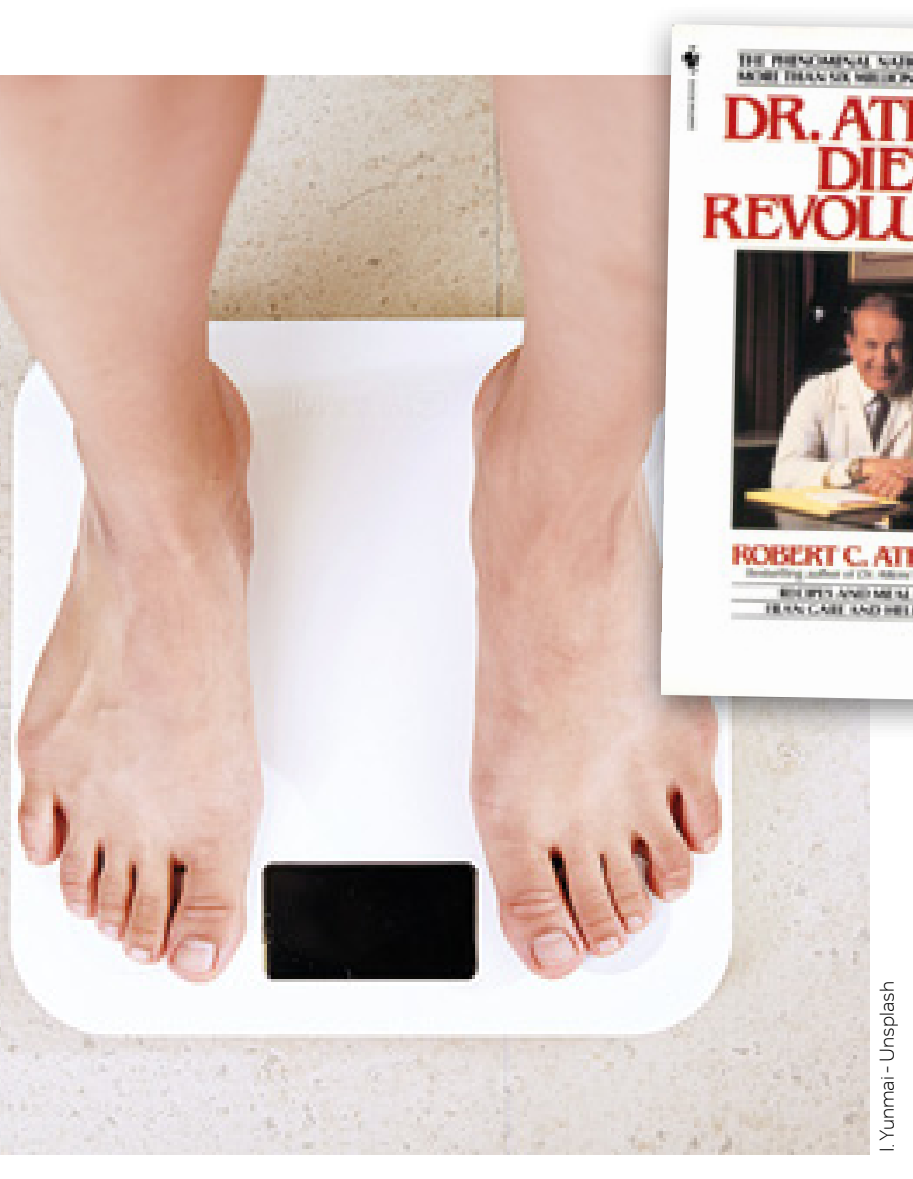

The Atkins diet achieves weight loss in the first few days by using up glycogen and body water. However, it has been shown that it can increase the amount of plasma cholesterol and uric acid, and patients who have stopped this diet have rapidly gained weight again.

In a world where health information abounds but it is sometimes difficult to tell evidence-based messages apart from the rest, it might be best to remember the following Hippocratic principle: «Let food be thy medicine, and let medicine be thy food», to which we would add that any dietary treatment should be monitored by dietitians and nutritionists. $\odot$

\section{REFERENCES}

Astrup, A., Meinert Larsen, T., \& Harper, A. (2004). Atkins and other lowcarbohydrate diets: Hoax or an effective tool for weight loss? The Lancet, 364, 897-899. https://doi.org/10.1016/S0140-6736(04)16986-9 Atkins, R. C. (1972). Dr Atkins' diet revolution. Bantam Books.

Bender, A. E. (1994). Dietas mágicas y otros errores. In F. Grande Covián, G. Varela, \& D. Conning (Eds.), Reflexiones sobre nutrición humana (pp. 357-389). Fundación BBVA.

Burroughs, S. (1976). The master cleanser. Burroughs Books.

Carstairs, C. (2014). 'Look younger, live longer': Ageing beautifully with Gayelord Hauser in America, 1920-1975. Gender \& History, 26, 332-350 https://doi.org/10.1111/1468-0424.12072

Christman, G. (2002). The Atkins diet: An unresolved debate. Nutrition Noteworthy, 5(1). https://escholarship.org/uc/item/1bp7f2bp

Drouard, A. (1998). Doctor Carton's diet and the «natural» diets. Cahiers de Nutrition et de Dietetique (France), 26, 332-350.

Ebers, G. (1873). Papyrus Ebers. Zeitschrift für ägyptische Sprache und Altertumskunde, 11(1-12), 41-46.
FAO. (n.d.). Glosario de términos. Retrieved November 30, 2019, from http://www:fao. org/3/am401s/am401s07.pdf

FESNAD. (2008). Día Nacional de la Nutrición. Retrieved November 30, 2019, from http://www. fesnad.org/?seccion=dinamico\&subSeccion= bloque\&idS=3\&idSS=32

FEN e Instituto de Nutrición y Trastornos Alimentarios de la Comunidad de Madrid (INUTCAM. (2009). Dietas y productos mágicos. INUTCAM.

Fletcher, H. (1903). The new glutton or epicure Frederick Stokes Company.

Hernáez, A., Zomeño, M. D., Dégano, I. R., PérezFernández, S., Goday, A., Vila, J., Civeira, F., Moure, R., \& Marrugat, J. (2019). Excess weight in Spain: Current situation, projections for 2030, and estimated direct extra cost for the Spanish health system. Revista Española de Cardiología, 72,916-924. https://doi.org/10.1016/j. rec.2018.10.010

IARC. (2018). Absence of excess body fatness. IARC Handbooks of Cancer Prevention.

Lesmes, I. B. (2016). Revisión crítica de las dietas de moda en el tratamiento de la obesidad. Anales de la Real Academia Nacional de Farmacia, 82 (extra issue), 195-205.

Ministerio de Sanidad, Consumo y Bienestar Social. (2018). Nota técnica. Encuesta Nacional de Salud España. Retrieved November 30, 2019, from https://www.mscbs.gob.es/estadEstudios/estadisticas/ encuestaNacional/encuestaNac2017/ENSE2017_notatecnica. pdf

Modi, N., \& Priefer, R. (2020). Effectiveness of mainstream diets. Obesity Medicine, 18, 100239. https://doi.org/10.1016/j.obmed.2020. 100239

National Institute for Health and Care Excellence. (2014). Obesity: Identification, assessment and management-Clinical guideline. Retrieved November 30, 2019, from https://www.nice.org.uk/guidance/ cg 189

RAE. (2019). Dieta. Diccionario de la lengua española. Retrieved November 30, 2019, from https://dlle.rae.es/dieta

Rolls, B. J., Kim-Harris, S., Fischman, M. W., Foltin, R. W., Moran, T. H., \& Stoner, S. A. (1994). Satiety after preloads with different amounts of fat and carbohydrate: Implications for obesity. American Journal of Clinical Nutrition, 60, 476-487. https://doi.org/10.1093/ajcn/60.4:476

Smit, H. J., Kemsley, E. K., Tapp, H. S., \& Henry, C. J. K. (2011). Does prolonged chewing reduce food intake? Fletcherism revisited. Appetite, 57, 295-298. https://doi.org/10.1016/j.appet.2011.02.003

Trimble, J. J. (1985). California Supreme Court Survey-A review of decisions: January 1984-July 1984. Pepperdine Law Review, 12(1), 215-369.

Varela, G., Núñez, C., Moreiras, O., \& Grande Covián, F. (1998). Dietas mágicas. Editorial Dirección General de Salud Pública. Consejería de Sanidad. Comunidad de Madrid.

WHO. (2000). Nutrition for health and development: A global agenda for combating malnutrition. World Health Organization.

WHO. (2016). Obesity and overweight. Retrieved November 30, 2019, from https://www.who.int/mediacentre/factsheets/fs311/en/

JOSÉ MIGUEL SORIANO DEL CASTILLO. Full Professor of Nutrition and Bromatology at the University of Valencia (Spain) and director of the Food \& Health Lab and Gastrolab-Fernando Sapiña, at the Institute of Material Science in the same university. He is director of the University Clinic of Nutrition, Physical Activity, and Physiotherapy, of the Lluís Alcanyís Foundation, and co-director of the Joint Research Unit in Endocrinology, Nutrition, and Clinical Dietetics of the University of Valencia-Health Research Institute Hospital La Fe. $\square$ jose_soriano@uv.es

$M^{a}$ INMACULADA ZARZO LLOBELL. Predoctoral researcher at the Food $\&$ Health Lab of the Institute of Material Science at the University of Valencia and is an Adjunct Professor within the Official Master's Degree in Personal and Community Nutrition at the University of Valencia (Spain).

$凶$ farmarzar@hotmail..com 